\title{
Farmer knowledge identifies a competitive bean ideotype for maize-bean intercrop systems in Rwanda
}

\author{
Krista B. Isaacs ${ }^{1 *}$, Sieglinde S. Snapp ${ }^{2}$, James D. Kelly ${ }^{2}$ and Kimberly R. Chung ${ }^{3}$
}

\begin{abstract}
Background: Plant genotypes are rarely developed for mixed cropping systems despite the potential of these systems to provide multiple ecosystem services. One of the most ubiquitously grown mixed cropping systems is a common bean (Phaseolus vulgaris L.) and maize (Zea mays L.) intercrop, but there is little consensus among researchers, and few known studies document farmer knowledge, about superior bean genotypes specifically for this intercrop system. Participatory plant breeding (PPB) is a well-accepted method of selecting varieties with farmers and could be a useful tool for identifying genotypes for intercrops. We used sole crop and intercrop PPB on-farm trials $(n=13)$ and interviews $(n=59)$ to document farmer knowledge about climbing bean genotypes and adaptation for intercrops in Rwanda, where smallholder farmers have traditionally grown beans and maize for generations.

Results: Qualitative analysis demonstrated that farmers considered distinct attributes for different cropping systems. In intercrops, farmer evaluation prioritized five factors: universal traits and trait-based competitive ability, intrinsic competitive ability, environmental adaptation, and management. Farmers consider intrinsic competitive ability crucial, whereas most other studies have neglected this attribute in intercrop breeding strategies. Furthermore, farmers identified specific attributes that constitute an intercrop bean ideotype: adaptation, restricted height, columnar plant structure, even distribution of pods, fewer leaves, and earlier maturity. Farmers also had specific techniques for testing cropping system and environment interactions.

Conclusions: PPB on-farm trial evaluations and interviews with farmers allowed us to combine traditional agroecological knowledge with plant breeding research to generate new knowledge that contributes to our understanding of intercrop breeding and bean traits for intercrops. Farmers demonstrated sophisticated understanding of methods to identify genotype adaptation, competitive ability, and specific traits that together create a bean ideotype for maize-bean cropping systems. Empowering farmers through on-farm testing of diverse genotypes, and even populations, could be a practical solution to expensive genotype by environment trials and improve the identification of highly adaptive and productive genotypes for diverse and resilient cropping systems.
\end{abstract}

Keywords: Breeding, Common bean, Farmer knowledge, Ideotype, Intercrop, Participatory plant breeding

\section{Background}

Plant genotypes adapted to smallholder environments, and diverse cropping systems are essential for improving food security and farmer livelihoods, but these heterogeneous environments present challenges to developing

\footnotetext{
*Correspondence: k.isaacs@cgiar.org

1 International Crops Research Institute for the Semi-Arid Tropics (ICRISAT), BP 320, Bamako, Mali

Full list of author information is available at the end of the article
}

appropriate genotypes. Plant breeding programs combined with participatory plant breeding $(\mathrm{PPB})^{1}$ methodologies that integrate farmer knowledge and preferences into the development and selection of new varieties are

\footnotetext{
${ }^{1}$ Following the work of several authors including Humphries et al. [1] we refer to participatory plant breeding (PPB) in the overarching sense of close collaboration between farmers and researchers, in which the degrees and stages of participation are on a continuum [2] and which describes a variety of methodologies, including participatory variety selection [3].
} 
one strategy that have increased the availability and adaptation of improved genotypes for smallholder conditions $[4,5]$. Decentralized, client-oriented PPB programs have the goal of increasing adoption of improved genotypes by ensuring that farmer criteria for genotypes are met $[6,7]$ and they include co-learning and sharing of knowledge between scientists and farmers [3, 8]. The PPB process has made considerable advancements in breeding farmerapproved, improved genotypes for various pure-stand crops including, among others, beans (Phaseolus vulgaris L.) [9], maize (Zea mays L.) [10], and pearl millet and sorghum [3]. These integrated PPB strategies may also provide certain insights into identifying genotypes suited for intercrops and mixed cropping systems.

Mixed farming systems, utilized by farmers worldwide $[11,12]$, provide multiple social and ecological services to the populations they support [13] and have been a subject of research for decades. These systems include diverse crop species often grown as intercrops, with two or more crops occupying a field at the same time. Summarized by Lithourgidis et al. [12] and examined by others, the principle advantages of intercropping include increased land use and resource efficiency, improved resilience, and reduced climatic risk $[14,15]$, all factors that contribute to food security. Disadvantages include the effort needed to identify appropriate cultivars for the system, increased labor and management [16], and complex design issues [17]. Recent work by Jackson et al. [18] advocates a biodiversity-based paradigm shift for agriculture, in which the diversity and potential resilience found in traditional, ecologically based mixed cropping systems serve as a base for improvements in cropping system design.

There are nearly 13 million hectares of common beans in production in Latin America and Africa, primarily on small farms, and bean-maize systems are the most common traditional system in both regions [19]. They are an important source of protein and the most important grain legume for human consumption in the world [19]. In Rwanda, the focal point of this study, beans are grown by $85 \%$ of farmers, with an average consumption of $48 \mathrm{~kg}$ per capita per year, and at the time of the research were second only to bananas in land area under cultivation (16\%) [20]. Beans were frequently intercropped with cereals, bananas, or root and tuber crops [20]. In the northern region of the country, climbing beans were often relay intercropped and broadcast with maize or sorghum, whereas in the south bush beans were intercropped. In the past few years, agricultural policy in Rwanda has begun to discourage intercropping [21].

Cereal-legume-based intercropping systems are also arguably one of the most efficient forms of intercropping due to the nitrogen-fixing properties of legumes, which are complementary to the high nitrogen demand of cereals [22] and marginal soils. Over the past few decades a handful of researchers has attempted to breed common bean cultivars for these cropping systems [2326]. The emphasis has been on genetic improvement of the less dominant bean component as many researchers have found no reduction of maize yields in intercrops $[24,27,28]$, although other research has shown a negative correlation between the yield of both climbing beans and maize, with $15-30 \%$ reductions in maize yield when intercropped but no reduction in yield in a relay intercrop [29].

Selection for performance within an intercrop can occur at different stages of the breeding process, but there is no consensus among researchers on the optimal time. A few studies have explored genotype improvement in the pre-breeding phase and the earliest stages of cultivar development [25, 26, 30]. Others reported on research initiated at the F4 and F5 generations, after a number of traits have been stabilized [23,31]. Finally, selections within intercrops have been made at the end of the breeding process with cultivars ready for release $[32,33]$. Many authors argue on practical grounds that selection for the intercrop environment should occur with advanced lines rather than early in the breeding process which involves a plethora of genetic material to screen $[23,26]$. At the same time, this may mean missed opportunities for improvement as there is evidence in both maize [25] and bean [26] that genetic variation for competitive ability can be lost when a crop is bred in a sole crop environment. However, monetary and logistical considerations are major deterrents to developing a breeding program focused on an intercrop environment.

Farmers have provided additional insights into how to test bean varieties for sole cropping. In the late 1980s Sperling et al. [34] conducted groundbreaking research in Rwanda that improved bean breeding for low-input systems by incorporating expert farmer knowledge into the selection of bean genotypes for sole crops. In concurrent work, Voss [35] found that bean farmers have particular methods for testing bean genotypes in different environments and cropping systems. He demonstrated that Rwandan farmers test a bean genotype in a sole crop first and if it performs well in the sole crop, they then test it in other environments including low fertility fields and broadcast intercrops Voss [35]. This is evidence that farmers have unique methods to select genotypes for intercropping systems and supports the conclusions of some scientists; however, there is limited documentation of farmer knowledge regarding specific traits for maizebean intercropping system.

Researchers have also attempted to understand the mechanisms involved in competitive interactions and the extent to which specific traits displayed in a sole crop 
might distinguish an intercrop competitive genotype from a non-competitive one [32,36]. The yield components in a sole crop have been proposed as a method for identifying a competitive genotype for the intercrop, but much uncertainty remains in this under-studied area. In this study, we used PPB focus groups and farmer interviews in Rwanda to explore the ways that farmers evaluate climbing bean genotypes in a sole crop and in an intercrop with maize. Our objectives were to understand how farmers evaluate genotypes in different cropping systems and to learn whether there are specific traits that farmers associate with improved competitive ability in the intercrop.

\section{Methods}

\section{Overview}

This qualitative study uses two forms of data, (1) onfarm participatory field trials with discussion groups and (2) interviews, to understand farmer knowledge about selecting bean genotypes for different cropping systems. The participatory plant breeding trials were conducted in northern Rwanda with seven farmer associations for two growing seasons during 2011-2012. Evaluations and discussion groups were carried out each season with these associations. The agronomic details of the on-farm trials, part of a larger study on genotype and cropping system interactions, are presented [28] and were an important reference point for discussion groups with the farmer associations. After the final harvests in 2012, interviews were conducted with these same farmers. Informed consent and institutional review board approval were obtained from Michigan State University (IRB\#: x101130), and the names and locations of the farmer associations remain confidential to protect the participants.

\section{Farmer associations and environments}

The research was carried out in the sub-humid tropics of Northern Province, Rwanda, at three agroecologies (Table 1). Seven farmer associations representing these agroecologies (characterized by elevation and edaphic features) were selected with the assistance of a local organization, Northern Rural Development, which works with farmer associations in the region.

Associations were approached to gauge interest in participating in planting climbing bean-maize field trials, and the purpose and activities of the trial were presented to the associations, including the provisions that would be supplied for the trial such as the bean seed cultivars and fertilizer. For all of the associations, there were also at least four workdays (for two planting times, PPB evaluations, and harvest) with community lunches. For each agroecology, there were two field sites in each season except at the Mid site in Season A there were three field sites, for a total of 13 replications of trials and PPB activities over two seasons (Table 1).

The three agroecologies, Low, Mid, and High, ranged in elevation (1600-2100 m.a.s.l.) and from sandy loam soil features to clay loam (Table 2), but there were no notable variations in terms of rainfall or temperatures. In addition to elevation, proximity of field plots to each other and similarities in soil characteristics delineated the differences between Low and Mid.

Soil fertility varied across agroecologies, where the Low sites were of medium fertility with total soil $\mathrm{N}$ ranging from 0.13 to $0.27 \%$, Mid sites were the least fertile with total soil $\mathrm{N}$ between 0.07 and $0.09 \%$, and high sites were the most fertile with total soil $\mathrm{N}$ between 0.17 and $0.43 \%$. Soil $\mathrm{pH}$ was generally ranged from 5.0 to 6.6 , with similar

Table 1 Demographic information from PPB and interview participants in Northern Province, Rwanda

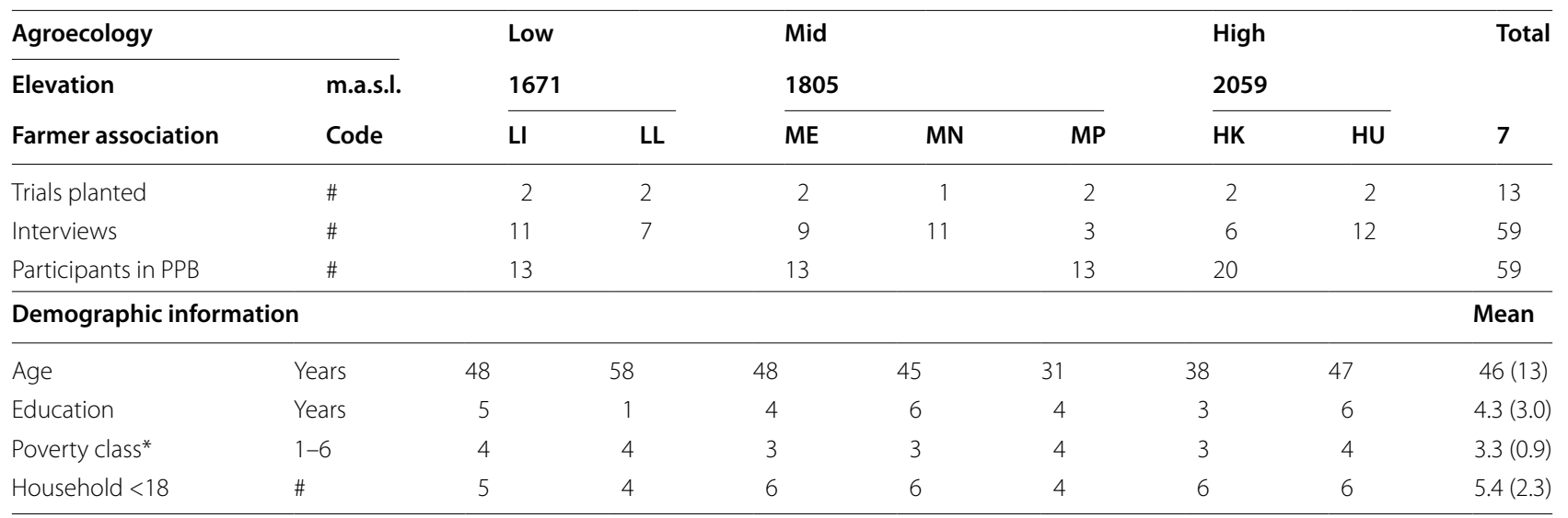

In some agroecologies, the PPB activities were combined at one trial location. For the demographic information, the values are averages for each farmer association site. Overall total and mean with standard deviation in parenthesis are presented. ${ }^{*}$ The Rwandan government developed six poverty categories that range from (1) 'abject poverty' to (6) 'the money rich.' Farmer association codes are confidential according to Internal Review Board policies 
Table 2 Characterization of agroecologies

\begin{tabular}{|c|c|c|c|c|c|c|c|c|}
\hline $\begin{array}{l}\text { Agroecologies } \\
\text { Unit }\end{array}$ & $\begin{array}{l}\text { Elevation } \\
\text { m.a.s.l. }\end{array}$ & $\begin{array}{l}\text { Soil type } \\
\text { Texture }\end{array}$ & $\begin{array}{l}\text { Clay } \\
\%\end{array}$ & $\begin{array}{l}\text { Sand } \\
\%\end{array}$ & $\begin{array}{l}\text { Total } N \\
\%\end{array}$ & $\begin{array}{l}\text { Organic C } \\
\%\end{array}$ & $\begin{array}{l}\text { Bray-P } \\
\text { ppm }\end{array}$ & Soil pH \\
\hline Low & 1671 & Sandy loam—silt loam & $9(0.7)$ & $50(18)$ & $0.2(0.1)$ & $2.2(1)$ & $94(32)$ & $6.4(0.2)$ \\
\hline Mid & 1805 & Sandy clay loam_clay loam & $31(5)$ & $39(11)$ & $0.1(.03)$ & $0.93(0.4)$ & $6(5)$ & $5.2(0.2)$ \\
\hline High & 2059 & Silt loam-loam & $16(8)$ & $34(5)$ & $0.3(0.3)$ & $2.93(3)$ & $10(6)$ & $6.2(0.5)$ \\
\hline
\end{tabular}

Soils were collected from the 15-cm topsoil depth each season in 2011 and 2012 in Northern Province, Rwanda. Data presented are averaged (std error) across trials sites for each agroecology

$\mathrm{pH}$ in the Low and High sites (6.2-6.8) and lower $\mathrm{pH}$ in the Mid sites (5.0-5.5) (Table 2).

The region has a bimodal rain distribution with two rainy seasons in one year, and yearly rainfall ranges from 1300 to $1600 \mathrm{~mm}$. Trials and PPB activities were conducted during Season B 2011 and Season A 2012. Season $B$ is the period of 'long' rains occurring from late February through June, and Season A is the period of 'short' rains occurring from early September through December.

\section{Agronomic trial description}

Farmer associations in each environment grew two cropping systems planted in a randomized complete block design (RCBD): a sole crop of climbing beans (SC) and a bean-maize intercrop (IC). These were single replicate trials with replication across environments. In each cropping system, six bean genotypes (five genotypes plus one bean mixture) were planted, for a total of 12 plots. Individual plots within the block were $3.0 \mathrm{~m} \times 4.0 \mathrm{~m}$ with uniform spacing between plots $(0.75 \mathrm{~m})$. According to farmer practice, the maize was planted first and the beans were planted 29-31 days later. Beans were planted in both systems at the same time. Farmers managed trials throughout the seasons, and fertilizer was applied according to farmer practice. In-depth details of the trial design are available [28].

The SC was planted according to the Rwanda Ministry of Agriculture regional recommendations, and all bean plants were staked according to farmer practice. Between-row spacing was $0.50 \mathrm{~m}$, and the distance between each plant within the row was $0.20 \mathrm{~m}$. Two seeds were planted per hole for a total bean population of 200,000/ha.

The IC design and plant density were based on input from farmers and Rwandan scientists. Beans and maize were planted in the same row, and there were two bean plants for each maize plant. Between-row spacing was $0.75 \mathrm{~m}$, and in-row spacing for beans was $0.1 \mathrm{~m}$ and for maize was $0.3 \mathrm{~m}$. Beans were planted on either side of the maize to facilitate bean climbing of maize stalks. The maize and bean populations in the IC were 44,400 and 106,700 plants/ha, respectively, for a total plant population $151,100 /$ ha.
For grain yield, the entire plot was harvested and weighed. Moisture content was determined on all grain using a moisture meter and corrected to 12 and $15.5 \%$ for beans and maize, respectively (Table 3 ).

\section{Maize and bean genotype descriptions}

The maize cultivar (Pool9A) used for all trials was a ubiquitously grown open-pollinated maize genotype originally selected for the Volcanic Highlands of Rwanda. It is in the class of Highland Late White Dent maize [37].

A plant breeder and the first author chose climbing bean genotypes for this study from the Rwerere Research Station in Northern Province, Rwanda. Four of the genotypes were cultivars to be released in 2012 (Gasilida, RWV 3006, RWV 2070, RWV 3316), one was released in 1991 (Ngwinurare), and there was a farmer-selected mixture of genotypes (FarmMix) unique to each association (Table 4). The genotypes varied in origin, with four of the cultivars incorporating germplasm developed at CIAT, an international center for bean improvement based in South America, the farmer derived mixture, and the other (Gasilida) a stabilized version of a Rwanda farmerdeveloped cultivar. Ngwinurare and the FarmMix were grown widely across the region, and the other genotypes were new to most farmers. All of the beans were largeseeded Andean-type cultivars except FarmMix, but they varied in terms of color, days to maturity, yield, and 100seed weight (Table 4). Estimated yields (from the Rwanda Agriculture Board) ranged from 3.80 to $4.25 \mathrm{mt} / \mathrm{ha}$.

FarmMix varied across all sites in terms of composition (3-10 different seed types), seed size, and the number of beans in the mixture. The seed types ranged from small to large, usually within the same mixture. Each association chose their own bean mixture. The median and mean number of genotypes per mixture was six.

\section{Qualitative data PPB discussions}

The PPB evaluation and discussion activities were conducted at physiological maturity with each farmer association in their own agroecology. These activities were carried out in the following manner. First, there was a discussion with the farmers to understand what they look 
Table 3 Bean yield averaged across sites and seasons in each agroecology

\begin{tabular}{|c|c|c|c|c|c|c|c|}
\hline \multirow[t]{2}{*}{ Agroecology } & \multicolumn{7}{|c|}{ Genotypes } \\
\hline & Gasilida & RWV 3006 & RWV 2070 & RWV 3316 & Ngwinurare & FarmMix & Mean \\
\hline \multicolumn{8}{|c|}{ Sole crop yield (Mt/ha) } \\
\hline Low & 3.4 & 2.7 & 2.5 & 2.6 & 2.9 & 2.8 & 2.8 \\
\hline Mid & 1.0 & 1.4 & 1.8 & 1.6 & 1.5 & 1.6 & 1.5 \\
\hline High & 3.4 & 2.7 & 3.6 & 2.8 & 2.1 & 2.8 & 2.9 \\
\hline Mean & 2.6 & 2.3 & 2.6 & 2.3 & 2.2 & 2.4 & 2.4 \\
\hline \multicolumn{8}{|c|}{ Intercrop yield (Mt/ha) } \\
\hline Low & 1.6 & 1.1 & 1.1 & 1.2 & 1.2 & 1.2 & 1.2 \\
\hline Mid & 0.5 & 0.4 & 0.5 & 0.6 & 0.8 & 0.6 & 0.6 \\
\hline High & 1.2 & 1.0 & 1.3 & 1.2 & 1.0 & 1.5 & 1.2 \\
\hline Mean & 1.1 & 0.8 & 1.0 & 1.0 & 1.0 & 1.1 & 1.0 \\
\hline
\end{tabular}

Table 4 Characteristics of bean cultivars evaluated in PPB trials during 2011-2012 in Northern Province, Rwanda

\begin{tabular}{|c|c|c|c|c|c|c|}
\hline \multirow[t]{2}{*}{ Characteristics } & \multicolumn{6}{|l|}{ Genotypes } \\
\hline & Gasilida & RWV 3006 & RWV 2070 & RWV 3316 & Ngwinurare & FarmMix \\
\hline Farmer name & Gasilida & Umweru & Kaki & Umutuku & Ngwinurare & Imvange \\
\hline Origin & Farmer & CIAT/RAB & CIAT/RAB & CIAT/RAB & CIAT/RAB & Farmers \\
\hline Release date & 2010 & 2012 & 2010 & 2012 & 1991 & $\mathrm{~N} / \mathrm{A}$ \\
\hline Germplasm & Improved landrace & Improved & Improved & Improved & Improved landrace & Mixture of landraces \\
\hline Days to maturity & 93 & 120 & 110 & 110 & 93 & $90-105$ \\
\hline Seed color & Purple & White & Beige & Red & Kidney & Mix \\
\hline 100-seed weight (g) & 48.3 & 52.0 & 53.6 & 52.0 & 49.2 & 46.9 \\
\hline Flower color & Pink white & White & Pink & Pink & Pink & Purple pink white \\
\hline Yield (mt/ha $\left.{ }^{-1}\right)$ & 4.25 & 3.8 & 4.25 & 4.0 & 4.24 & Variable \\
\hline Disease resistance & $\begin{array}{l}\text { Anthrac-nose, root } \\
\text { rot, rust }\end{array}$ & $\begin{array}{l}\text { Anthrac-nose, root } \\
\text { rot, BCMV }\end{array}$ & $\begin{array}{l}\text { Anthrac-nose, root } \\
\text { rot, BCMV }\end{array}$ & $\begin{array}{l}\text { Anthrac-nose, root } \\
\text { rot, BCMV }\end{array}$ & Root rot, BCMV & Unknown \\
\hline Fe (ppm) & 65 & $73^{*}$ & 65 & $95^{*}$ & 65 & Unknown \\
\hline
\end{tabular}

Source is official release information from the Rwanda Agricultural Board (RAB)

CIAT International Center for Tropical Agriculture

* These varieties are considered biofortified with Fe and Zn

for when evaluating bean varieties in the different systems. These discussions and criteria informed the evaluation of the genotypes and the analysis of the PPB focus groups. Second, focusing on a single cropping system at a time, the farmers walked through the field in their own agroecology and examined genotype performance. Third, after this walk-through inspection, the farmers voted anonymously with colored ribbons for their preferred genotypes for that one system. These votes were then tallied and visually displayed for each genotype. Finally, an open-ended discussion followed in which farmers were asked what they liked and disliked about each genotype in this system, with emphasis on understanding which traits were important. The exact exercise was repeated for the remaining cropping system. The order in which the cropping systems were voted on and discussed was random. Care was taken to hear comments from both men and women, although there were more women than men in all of the PPB activities.

PPB was carried out both seasons, but the results presented here were from the second season discussions (Season A) because it was expected that farmers' observations were cumulative, building on experience and observations from the first season (including cooking and tasting of the varieties). The first author and the same research assistant facilitated all activities in the local language with direct translation as needed. Two enumerators were present during all PPB activities and recorded the comments from farmers and later translated into English from the handwritten notes. 
During the second season there were 5 discussion groups with a total of 59 participants present for the PPB activities, and these were the members of the farmer associations that planted the field trials; approximately, 5 members were not present. There were 13 farmers from the Low environment, 26 at the Mid, and 19 at the High (Table 1). In Low, PPB discussions were held in one location with farmers from both associations; likewise for Mid, except MP in which the discussion and evaluation were conducted at MP; in High the discussions were held in both sites with the farmers from both associations. In the High, both farmer associations evaluated both field sites because the environments were distinct: One site was in the valley with richer soil, and the other was on a steep-sloped hillside with eroded soils. This variation in methodology was due to farmer preference, agroecologies, quality of the demonstration field, and logistics.

\section{PPB discussion analysis}

The recorded comments from the PPB discussions (SC and IC) in Season A were coded using emergent themes [38] to answer the question: 'How do farmers evaluate genotypes?' In the first phase of coding, patterns and traits that farmers discussed were identified. From this phase, it became clear that when farmers discussed most factors, such as adaptation, pod size, or birds eating the flowers, they typically included explanations of how this affected yield. In order to understand the factors other than yield behind farmers' comments, yield was considered separately. In this second phase of coding where yield was considered separately, farmers' evaluation of genotypes fell into 13 themes (Table 5; Fig. 1) that were clustered into six larger categories of yield, plant traits, adaptive qualities, market and labor attributes, nutritional and cooking quality, and other. The themes plant traits and adaptive qualities are presented in Table 6 . Men and women's comments in each theme and each genotype were tallied, and frequencies were calculated for each theme and cropping system (Table 5; Fig. 2).

The text from the PPB discussion groups was also analyzed for each genotype. A text summary was written to encapsulate farmers' comments about each particular genotype using the same themes. Salient comments from these summaries were placed in a thematic table (Table 6). Direct quotes and text summaries were used to support analysis in both the results and methods.

\section{Interviews}

At the end of the second season the first author and same research assistant conducted individual interviews with members of the farmer associations. A specific portion of this interview is presented and analyzed here. The interview included demographic information and three open-ended questions about how farmers identify genotypes for an intercrop cropping system, building on the information learned from the PPB focus groups and informal on-going discussions. The questions were designed to learn whether farmers believe there are plant traits that improve performance in the intercrop and if so, to explain what those traits are and how they improve performance. The three questions asked of participants were:

1. In general, according to your observations, are there plant characteristics in a bean genotype that make it better for an intercrop? If so, what are they?

2. Which bean genotype or mixture from our research do you think is the best in an intercrop with maize?

3. Why was it the best in the intercrop? Do you have any observations about the genotype that made it do better in the intercrop?

From the participating farmer associations, 59 interviews were obtained that met quality standards (61 people were interviewed), including two association members that did not participate in the PPB activities.

\section{Interview data analysis}

Descriptive statistics were used to analyze the demographic data from the interviews, and averages were calculated and presented by farmer association community (Table 1).

The short-answer questions from the individual interviews were coded using emergent themes [38] to answer the question, 'Are there specific characteristics farmers look for when selecting genotypes for an intercrop?' Text summaries were written for each theme (Table 7). The themes that emerged were comparisons, experimentations, trait-based competitive ability, intrinsic competitive ability, management, and adaptation. Again, direct quotes and text summaries were used to support analysis in both the methods and results (Table 7).

\section{Results \\ Demographics of farmer association members}

The farmer demographics varied somewhat across environments in terms of age, years of education, and poverty level (Table 1). In general, the farmers from the Mid and the High were the most similar. The Rwandan government established 6 poverty categories that range from a score of 1-'abject poverty' to 6-'the money rich' [39]. In this study 'class' was based on these categories and was self-reported (Table 1). Farmers were poorest at the Mid environment with a mean class of 3 or 'the poor', and farmers in the Low and High environments were a mean class of 4 or 'the resourceful poor.' Average landing hold 
size ranged from 0.3 to 1.0 ha. Farmers in High had the most land, and Farmers in Low had the least. The gender composition of the farmer associations was mixed, and participants overall included more women (43 women and 16 men in the PPB discussions and a similar distribution in the interviews). In Rwanda, there is mixed information if beans are considered specifically a women's crop but previous work identified women as bean experts [34] and this likely was part of the reason women were more than represented in the farmer associations identified with the partner NGO. When asked directly, both men and women stated the crops were shared responsibilities.

\section{Thematic categories from PPB}

The data from the PPB open-ended discussions demonstrated farmer knowledge of traits associated with genotype suitability for an intercrop. Six major thematic categories of trait farmers use to select bean genotypes in any cropping system emerged from the PPB discussion data (Table 5). In order of frequency the major themes were as follows: yield, plant traits, adaptive qualities, nutritional and cooking quality, market and labor attributes, and other. Within each thematic category were other themes, which are discussed and defined below.

\section{Yield theme}

Across both systems, the most commonly mentioned trait was yield (mentioned 128 times) (Table 5) and it was inseparable from discussion of other traits. Farmers almost always discussed how yield was affected by other themes such as plant architecture, competition, and adaptation. For example, farmers associated plant traits such as pods/plant and seed weight with production, as in this quote about Ngwinurare: 'There are enough pods and big seeds inside which leads to adequate production which in turn increases the farmer's welfare.' Thus, this quote was included in the themes 'yield' and 'plant architecture.' In the SC, men and women mentioned yield with nearly the same frequency ( 25 and $27 \%$, respectively), while in the IC, men discussed yield $30 \%$ of the time and women discussed it $24 \%$ (Table 5). Yield was an essential attribute, and sole crop bean yields were often more than double that of intercrop yields, but parallel research to this revealed that farmers also valued other features of intercrops: the ability to harvest more than one crop from limited land, nutritional diversity, marketability of diverse products, community sharing, and reduced risk [21].

\section{Plant traits theme}

After yield, the most common thematic category was plant traits, which included the themes 'plant

Table 5 Frequency of themes discussed by farmers in PPB discussion groups conducted in 2012, Northern Province, Rwanda

\begin{tabular}{|c|c|c|c|c|c|c|c|c|}
\hline \multirow[t]{2}{*}{ Thematic categories } & \multirow[t]{2}{*}{ Themes } & \multicolumn{3}{|c|}{ Sole crop (SC) } & \multicolumn{3}{|c|}{ Intercrop (IC) } & \multirow[t]{2}{*}{ Total SC + IC } \\
\hline & & Women & Men & Total & Women & Men & Total & \\
\hline Yield & Yield & 35 & 23 & 58 & 43 & 27 & 70 & 128 \\
\hline \multirow[t]{4}{*}{ Plant traits } & Plant architecture & 6 & 8 & 14 & 23 & 7 & 30 & 44 \\
\hline & Maturity & 15 & 4 & 19 & 12 & 9 & 21 & 40 \\
\hline & Pest and disease & 8 & 6 & 14 & 9 & 7 & 16 & 30 \\
\hline & Total & 29 & 18 & 47 & 44 & 23 & 67 & 114 \\
\hline \multirow[t]{3}{*}{ Adaptive qualities } & Competition & 3 & 1 & 4 & 20 & 8 & 28 & 32 \\
\hline & Adaptation & 15 & 11 & 26 & 17 & 10 & 27 & 53 \\
\hline & Total & 18 & 12 & 30 & 33 & 18 & 55 & 85 \\
\hline \multirow[t]{3}{*}{ Nutritional and cooking quality } & Nutrient qualities & 11 & 3 & 14 & 5 & 4 & 9 & 23 \\
\hline & Cooking qualities & 18 & 10 & 28 & 15 & 5 & 20 & 48 \\
\hline & Total & 29 & 13 & 42 & 20 & 9 & 29 & 71 \\
\hline \multirow[t]{3}{*}{ Market and labor attributes } & Market & 13 & 11 & 24 & 11 & 5 & 16 & 40 \\
\hline & Labor and stakes & 6 & 1 & 7 & 9 & 1 & 10 & 17 \\
\hline & Total & 19 & 12 & 31 & 20 & 6 & 26 & 57 \\
\hline \multirow[t]{5}{*}{ Other } & Life-span & 5 & 5 & 10 & 6 & 4 & 10 & 20 \\
\hline & Information & 4 & 0 & 4 & 5 & 4 & 9 & 13 \\
\hline & Aesthetic & 1 & 1 & 2 & 2 & 0 & 2 & 4 \\
\hline & Total & 10 & 6 & 16 & 13 & 8 & 21 & 37 \\
\hline & Total & 140 & 84 & 224 & 177 & 91 & 268 & 492 \\
\hline
\end{tabular}

Absolute values reported here are based on thematic coding of recorded discussion groups. There were 16 men and 43 women participants ( $n=59$ ) 
architecture,' 'maturity', and 'pest and disease' issues (Fig. 1). Within the theme 'plant architecture', farmers commented on plant attributes that included yield components such as pods/plant, seeds/pod, seed size; positions of pods on the plant, vine thickness, the quantity of flowers, plant height, and biomass. For performance within the SC, 14 farmers used plant architecture as a way to describe their acceptance or rejection of a genotype, while in the IC, twice the number of farmers, 30, referred to plant architecture (Table 5). Farmers preferred genotypes in the IC that had pods starting from the bottom of the plant and growing to the top (Gasilida and RWV 3316). Genotypes that were very tall or overgrew the maize were problematic (RWV 3006 and RWV 2070) as were pods with few seeds.

The plant trait theme 'maturity' referred to the length of time to plant maturity. Farmers mentioned maturity 40 times in both cropping systems (Table 5). Farmers preferred short-duration genotypes (Gasilida) but liked some genotypes so well (RWV 2070) they were willing to accept the longer time to maturity. They conferred that short-duration genotypes were good at 'fighting hunger,' while they wait for the maize harvest and complained about some genotypes (RWV 3006, RWV 2070, and RWV 3316) taking too long in the field. In the IC, the longer time to maturity increased competition according to some: For example, '(RWV 3006 in the IC) takes a long time to mature which leads to increased competition between beans and maize and lowers production.' Several farmers commented on different stages of maturity in the FarmMix being problematic: 'Imvange has different maturing stages due to different types of seeds that are grown together, making it difficult to harvest (at once).

'Pest and diseases,' the final theme in the plant traits category, was defined as the presence (or lack of) or resistance to disease or pests. It was mentioned 30 times in both cropping systems (Table 5). A major concern for farmers in most of the genotypes was the attractiveness of the bean flower to birds. Farmers complained that birds eat the flowers, which in turn reduce the yield. Genotypes Gasilida, RWV 3006, and RWV 2070 were the most affected by birds, whereas RWV 3316 and Ngwinurare were minimally affected and FarmMix was not at all. Damage from birds was reduced in the intercrop. A few farmers said that Gasilida, RWV 3006, Ngwinurare, and FarmMix were generally affected by disease.

\section{Adaptive qualities theme}

Adaptive qualities, which include the themes 'adaptation' and 'competition', were mentioned 85 times, although more frequently in the IC (55) than in the SC (30) (Fig. 1). Adaptation was defined as the ability to adapt to the

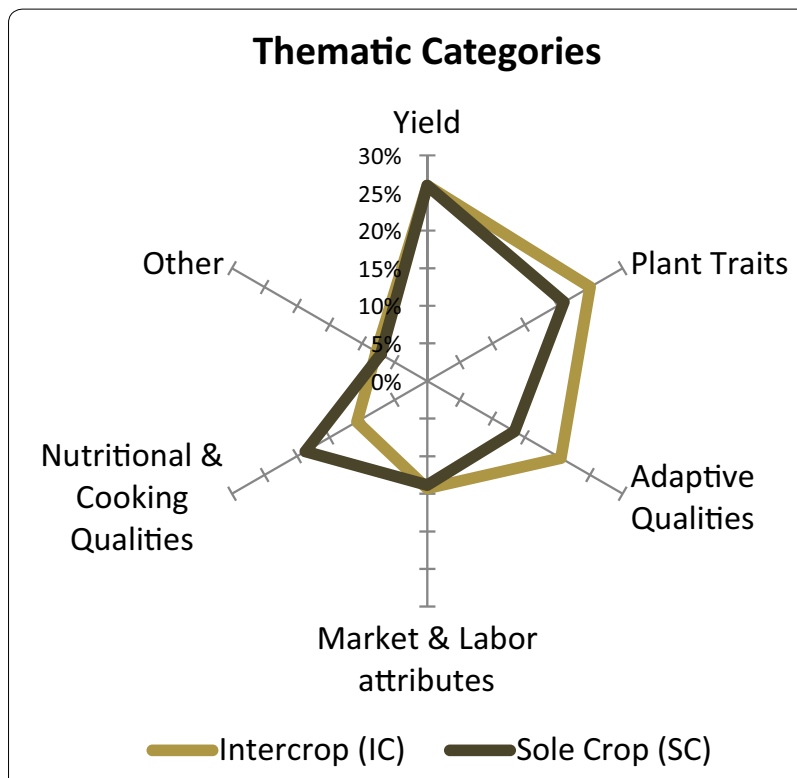

Fig. 1 Relative frequency of emergent thematic categories from PPB discussions ( $n=59$ ) conducted in 2012, Northern Province, Rwanda

region in terms of climate, soil types and soil fertility, climate, weather (wind and rain), and different seasons. It was mentioned 26 times in the SC and 27 times in the IC (Table 5).

Competition was defined as comments about the two crops or genotypes competing with each other for resources. This category included issues such as shading, maturity, and plant architecture when the farmer referred explicitly to those issues in relationship to competition. Competition was mentioned 4 times in the SC and 28 times in the IC (Table 5). This indicates greater farmer concern for competition between species (in the IC) than competition within a species (SC).

\section{Nutritional and cooking quality theme}

The thematic category nutritional and cooking quality was discussed a total of 71 times across both cropping systems (Table 5; Fig. 1). This category included the themes 'nutritional qualities' and 'cooking qualities.'

The theme 'nutritional qualities' included any text that referred to food attributes relating to calories, protein, or sustenance for the human body in terms of nutrients. In other unrelated works, these farmers have been exposed to campaigns on iron and zinc biofortified varieties and the protein value of beans. Farmers discussed the nutritional value of genotypes approximately 11 times in either cropping system (Table 5). For example, a farmer said of RWV 3006, 'It's full of protein, calories and various vitamins for the body. 
The theme 'cooking qualities' was applied when the flavor of the beans or leaves was discussed, when farmers commented about the time it takes to cook the beans, or if the beans require more or less firewood (Table 5). Farmers mentioned cooking qualities approximately 24 times in either system. They said genotypes RWV 2070, RWV 3006, and Ngwinurare required less fuel to cook, whereas the farmer mixture took more time to cook because some beans were ready, while others needed more cooking time. Farmers liked both the beans and leaves for various reasons. For example, 'It tastes so sweet and fresh leaves fight hunger' and it 'gives less difficulties to cook because it is not very hard by nature', e.g., the seed is not hard.

\section{Market and labor attributes theme}

Farmers discussed market and labor attributes 57 times overall and an average of 28 times in either cropping system (Fig. 1). This category included the themes 'market' and 'labor and stakes' (Table 5). The theme 'market' was applied when farmers mentioned the value of the genotype on the market. For example, farmers complained about a genotype being less well known on the market (RWV 2070) or it being highly valued on the market (most genotypes). The theme 'labor and stakes' was defined as references to a specific trait that increases or decreases the required labor to produce the genotype or to stakes, which are a labor-intensive and a resource issue. For example, farmers complained that RWV 2070 was so tall and strong that it required larger stakes, which were difficult to find. Or, in reference to FarmMix, farmers said that it required more labor during harvest because the genotypes matured at different times. There were on average 8.5 comments in either system about labor or stakes (Table 5 ).

\section{Other theme}

The final thematic category of 'other' includes various themes that did not have many comments. These include the themes 'aesthetics,' 'information', and 'lifespan' (Table 5). Farmers discussed these themes evenly between the cropping systems for a total of 37 times (Fig. 1). A handful of farmers mentioned the color of the beans. The theme 'information' referred to comments that said there was or was not enough information about the genotype. Farmers related this lack of information back to the value on the market or an inability to grow the genotype properly (Table 5 ).

\section{Gender analysis of themes from PPB}

There were differences between men and women's comments by cropping system. In the $\mathrm{SC}$, women discussed plant maturity and labor issues more than twice as much as men (Fig. 2). Women find and maintain stakes for the beans, and they are a limited resource. In the SC, men focused on plant architecture, market attributes, and adaptation more often than women. In the IC, women's comments were focused on plant architecture and competition, while men were more concerned about plant maturity, pest and disease, and slightly more about adaptation (Fig. 2).

\section{Genotype preference from PPB}

Gasilida was favored across sites and was generally the best yielding (Table 2). Multiple farmers from all of the agroecologies liked that Gasilida produced pods from the bottom of the plant to the top and that there were very

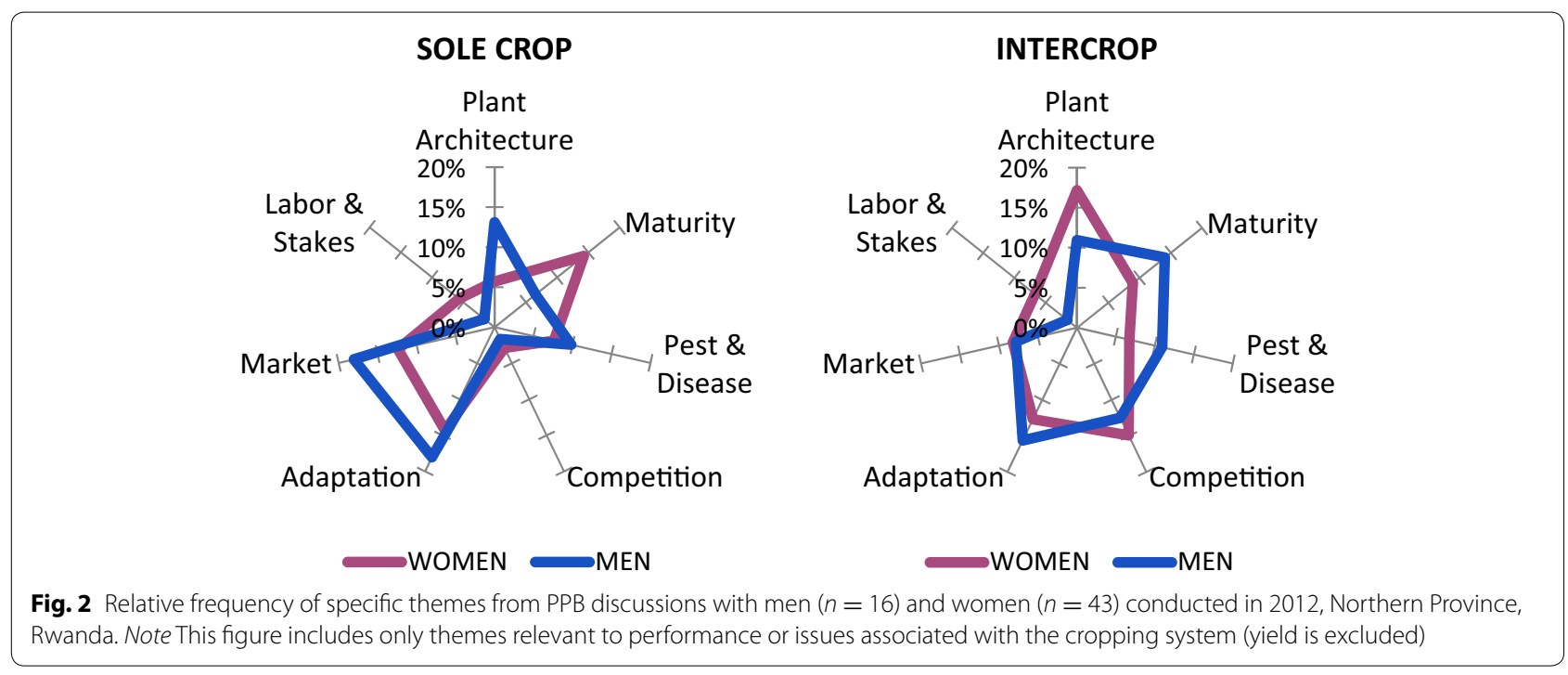




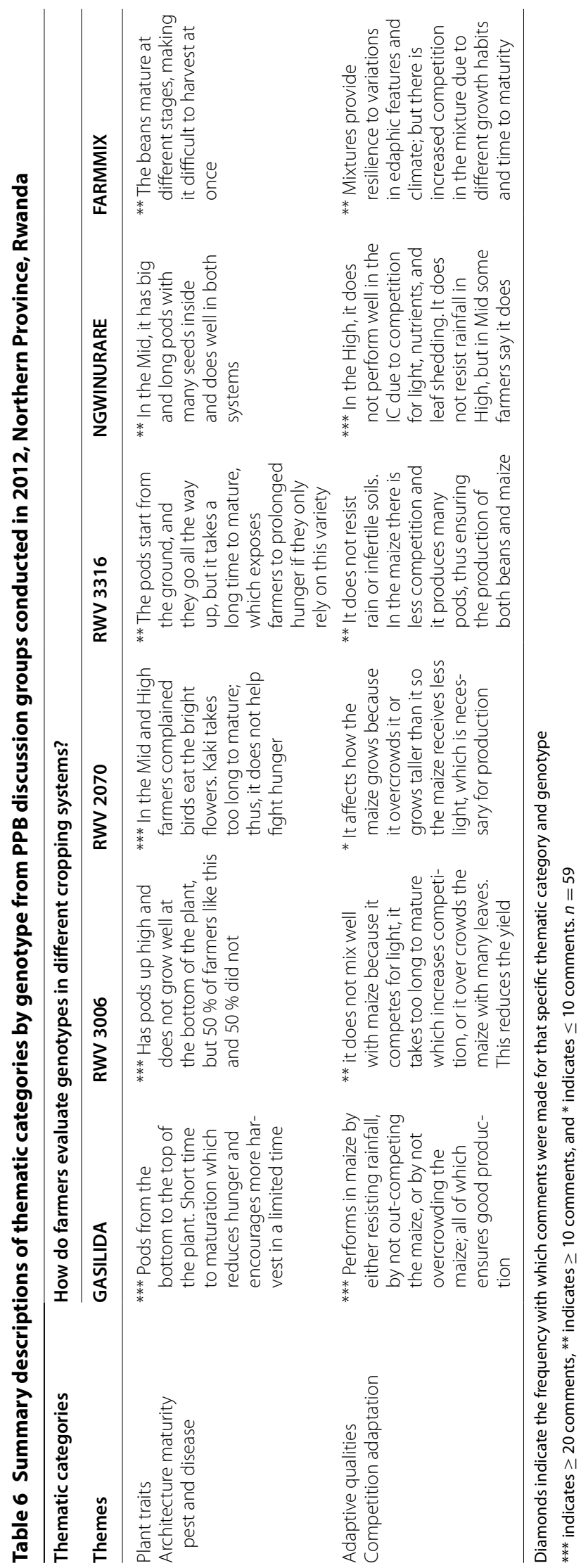


big and long pods. Farmers said these traits increased production and improve the standard of living. Farmers from all of the environments said that Gasilida does well in the maize by either resisting rainfall (presumably referring to disease resistance under wet conditions), by not outcompeting the maize, or by not overcrowding the maize (Table 6). However, farmers also said Gasilida was problematic for disease and pests (birds). Many farmers from all of the environments said that Gasilida tastes very sweet and has various nutrients, which are necessary for the human body, and it provides great support to the body because of its calories and proteins. Farmers from each environment said it was highly valued on the market due to these qualities.

RWV 3006 was less preferred across sites. Most comments about RWV 3006 from farmers were concerns about the plant architecture and competition with maize. Farmers from all of the environments said that RWV 3006 does not mix well with maize because it competes with maize for light, it takes too long to mature which increases competition, and it overcrowds the maize with many leaves. Farmers also did not like that the pods tend to grow up high but not at the bottom of the plant. There were problems with birds eating the bright flowers, and farmers in the Mid found that RWV 3006 was not resistant to rain and heavy rainfall caused damage to it. In the Low, farmers said it grew poorly from the beginning. There were comments from each environment about RWV 3006 not being well known which caused problems for marketing or handling.

There were mixed reviews of RWV 2070 across sites. Farmers from the Mid said that RWV 2070 grew well in the SC with long pods and many seeds, but in the Low farmers said the opposite. In the IC, some farmers said RWV 2070 grows taller than the maize, overcrowds it, or there are empty pods and too much biomass, reducing the yield of both crops. The bright pink flowers attract birds, which eat the flowers. Farmers from all the environments said that it takes too long to mature and does not help fight hunger. Farmers also complained about a lack of resistance to rainfall and insufficient adaptation to climate variation. Concerns were also expressed about it not being known on the market, so not highly valued.

Farmers from all of the environments said that RWV 3316 performed well in the IC because there was less competition with the maize and it produced many pods, ensuring production of both crops. However, they said it 'takes a long time to mature which exposes farmers to prolonged hunger if they only relied on this one genotype.' Farmers found it was not resistant to infertile soils in the Mid, and a few from each environment said it did not resist rain. All farmers agreed it tasted sweet and it has various nutrients for the human body.

There were mixed reviews about Ngwinurare across sites. In the High farmers agreed Ngwinurare does not grow well in either system. They said they did not like the genotype because it does not resist rainfall, it is outcompeted by the maize, and it easily succumbs to disease in the field. In the Mid farmers had mixed opinions but were generally positive about Ngwinurare. Farmers in the Low and Mid said it has big, long pods in both systems and a short maturation time. Some of these farmers said Ngwinurare was unaffected by the rain, unlike other cultivars, while other farmers said this cultivar did not grow well on infertile soils. Farmers from all the environments said it tasted sweet, and a few said it had important qualities for the human body.

\section{Farmer assessment of suitability for an intercrop from interviews}

Data from the interviews were used to determine whether and how farmers identify genotypes for growth in an intercropping system. Emergent analysis of the short-answer questions showed that farmers used various forms of observation and comparison between genotypes to determine the suitability of a genotype for the intercrop system. The interview data revealed that they did these types of comparisons and experimentation previously, in addition to the context of participating in these PPB trials.

From the 59 interviews, it was found that farmers from all of the environments consider up to five factors when determining the suitability of a genotype for an intercrop (Table 7). These factors were as follows: universal plant traits, trait-based competitive ability, intrinsic competitive ability, adaptation, and management. Farmers said they look at traits and assess the bean plant with the same traits they would consider in a sole crop (universal plant traits), or they associate certain traits with competitive ability in the intercrop (trait-based competitive ability). In addition to traits, farmers indicated that genotypes might have an inherent quality that makes them competitive in the intercrop (intrinsic competitive ability). Farmers said they also consider management strategies (management) and adaptation to the environment (adaptation) when identifying suitable genotypes (Table 7).

\section{Universal and trait-based competitive ability from interviews}

The theme 'universal plant traits' was discussed by $80 \%$ of the farmers in the short-answer interviews. This included references to plant traits such as pods/plant, seeds/pod, and plant height. This theme was applied when farmers indicated they identified a genotype by looking at these 


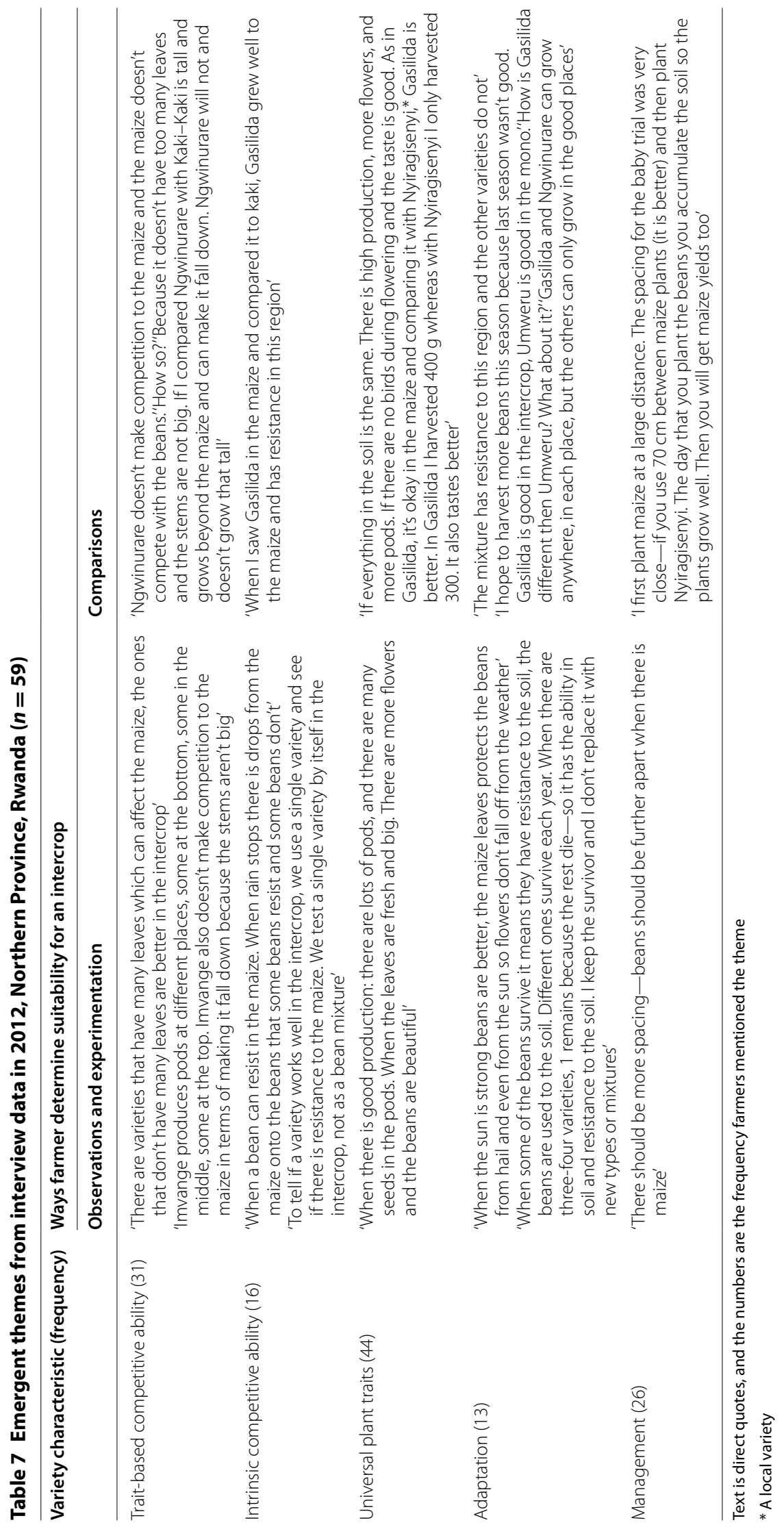


types of traits, which can be used to assess genotype performance in any type of cropping system (Table 7).

The theme trait-based competitive ability was applied when farmers linked the plant trait to competitive ability; this occurred in interviews with $56 \%$ of the farmers. Competitive ability traits included competition for light, plant height and competition, and plant architecture and competition (Table 7). Farmers related the quantity of leaves to competition. Examples include 'Gasilida was growing well to the maize. The leaves are not too many which helps avoid competition to the maize, but they also weren't too few' and 'Gasilida doesn't have many leaves... so the sunlight can penetrate through to the plants.' Another farmer also said leaves near the bottom of the plant are important for light competition: 'the leaves don't avoid the sunlight (and are able to) penetrate to the ground.'

Farmers expressed concern about plant architecture that was too competitive in the intercrop and stated plant height and pod weight at the top of the bean plant caused the plant to fall over, or lodge. They said genotypes such as RWV 3006 'overcrowd' the maize with 'too many pods on top' and RWV 2070 overgrew the maize and reduced competitive ability. A farmer in High said, 'Kaki creeps longer on the top of maize thus leading to difficulties in harvesting both maize and beans.' In contrast, Ngwinurare was appreciated for its shorter stature, 'Ngwinurare doesn't make competition to the maize and the maize doesn't compete with the beans because it doesn't have too many leaves and the stems are not big. If I compared Ngwinurare with kaki, kaki is tall and grows beyond the maize and can make it fall down. Ngwinurare will not and doesn't grow that tall'

There was mixed evidence about the effect of the girth of the bean vine on the maize plants. Some farmers said thin or small vines were better for competition, 'Imvange (FarmMix) also doesn't make competition to the maize in terms of making it fall down because the stems aren't big' but others said that a thick stem was good in the intercrop (you can tell a genotype is good in the intercrop when) 'the beans grow well to the maize-when the stem is big, there are more pods, and there are fresh beans. When the pods are long.'

\section{Intrinsic competitive ability from interviews}

While over half of farmers mentioned trait-based competitive ability, about $30 \%$ also referred to an intrinsic competitive ability they observed (Table 6). Intrinsic competitive ability was defined as an innate quality of the genotype that enabled it to 'grow well to the maize' or 'resist the maize' and when questioned further, farmers did not associate certain traits with this ability to resist the maize. They considered it a separate quality from other traits. For example, a farmer from Mid said, 'Gasilida grows well to the maize and produces fresh beans from the ground to the top and has more pods' and a farmer from High said, 'Some genotypes can resist being close to the maize, others cannot.' This intrinsic ability may be related to genetic variation in competitive ability or a genetic resistance to disease. A farmer in High elaborated on what she meant by an ability to resist: 'When a bean can resist in the maize. When the rain stops there are drops from the maize onto the beans that some beans resist and some beans don't...Some genotypes can resist being close to the maize, others cannot.' Other farmers made similar points, 'It is better in the maize and it is good to eat. I don't know why it does well in the maize, I just tried it to find out.'

\section{Adaptation to environment from interviews}

The concerns farmers expressed in the interviews about adaptation were very similar to what emerged from the PPB discussions (Tables 5, 6). The theme adaptation was applied when farmers referenced the genotype adaptability to the region, either edaphic or climate features, and was an important consideration when identifying genotypes for the intercrop. Twenty-four percent of farmers discussed adaptation in the interviews. Often Gasilida, Ngwinurare, and FarmMix were singled out for this feature in relationship to the local environment. For example, a farmer said, 'Gasilida is good in the intercrop, RWV 3006 is good in the sole crop. Gasilida and Ngwinurare can grow anywhere, in each place, but the others can only grow in the good places' and 'When some of the beans survive it means they have resistance to the soil, the beans are used to the soil.' Farmers also discussed some genotypes having resistance to the rain or the particular season, 'It also depends on the type of variety-there are types that are better for each period.'

\section{Management strategies from interviews}

Forty-seven percent of respondents considered management important in intercropping systems, but diverse opinions were expressed. Some farmers were inclined to manipulate plant density, timing of planting, and plant type (Table 7). In terms of plant density, many farmers were in agreement about increasing the spacing in the intercrop. For example, a farmer in Low said that an intercrop is better 'When there is different spacing than now. When the space is big the competition is lower and then there is good production for both. Due to good spacing, working inside is easy.' Farmers had different opinions about when to plant the beans, varying from 2 to 4 weeks after maize planting. One farmer summarized the concept well, 'When given (the right) time between planting, light can make it through to the beans.' 


\section{Discussion}

\section{Genotype evaluation}

Farmers evaluated genotypes for intercrops through observations in the field, experimentation, and comparisons with other varieties. Almost every farmer from the interviews discussed several of five thematic attributes that effect genotype performance, and the themes were repeated in all environments. Researchers have also evaluated genotypes intended for an intercrop by experimenting with management strategies and using plant traits such as yield, pods/plant, or flower set [32, 40], but no clear picture has emerged on which morphological traits, or combination of traits, are the most important for bean-maize intercrop system. Farmers' strategies both confirm researchers' findings and lend new insights into how to identify genotypes for intercrop systems, supporting the notion that there are 'significant extra benefits' for farmers and scientists engaging in collegial partnerships [1].

Farmer insights into genotype evaluation strategies for different types of cropping systems were learned from the PPB discussions. Participants focused on different traits when they were evaluating germplasm for sole crop than for intercrop, and this varied with gender (Fig. 2). Farmers discussed plant architecture and adaptive qualities including competition, more frequently in the intercrop than in the sole crop (Fig. 1), and specifically women increased focus on plant architecture, whereas for men the importance of this factor was more similar between cropping systems. In the intercrop, men focused more on maturity. Some of these differences may be explained by the roles of men and women in field activities. While men may be more in control of harvest and purchasing inputs for issues such as disease and pests, women are in charge of collecting stakes for sole crop beans; and weeding, especially in densely planted intercrops [28]. Thus, women may be spending more intimate time in the bean fields and have more experience with types of plant architecture. These different perspectives add to our understanding of improved genotype performance in specific environments, and a comprehensive and accurate assessment of variation in knowledge systems requires genderbalanced analysis [41]. Indeed, from the discussions of plant traits an ideotype for intercrop varieties emerged inclusive of time to maturity and necessary plant attributes and an analysis exclusive of one group would have lost these valuable insights. Nonetheless, this study might have been strengthened with a more balanced representation of men.

\section{Plant traits}

There has been work attempting to identify plant traits that correlate with better performance in the intercrop
[42]. But besides yield components such as pods per plant, there is no clear story on which plant traits are best in the intercrop. In this study, a region where intercropping was ubiquitous and farmers have a long history of intercropping multiple different crops including beans and maize, farmers have criteria concerning which plant traits are important in an intercrop. These included characteristics such as columnar plant structure, plant height, leaf biomass, and stem thickness.

Farmers stated in the PPB discussions that shorter bean plants with a columnar plant type, where pods are set evenly from top to bottom, were preferred for an intercrop because taller plants overgrew the maize. More vigorous plant types can cause lodging of the maize plant, which can be further antagonized if the pod load is concentrated at the top of the plant. In accordance with these farmer observations, others found that there were minimal genotype by cropping system interactions in bush bean-maize intercrops [30] and in bush bean-banana intercrops [43], indicating that the short-statured plant was less affected by the cropping system environment. Type IV climbing beans can have as much as three times the yield as bush beans and fill distinct niches in highland systems [44]. The identification of genotypes, such as Gasilida and Ngwinurare, that have restricted height but still maintain the higher yield advantage of a climbing bean, is an important finding for developing intercrop cultivars.

Farmers in this study identified light competition as a critical variant in genotype performance and associate this with both plant height and leaf biomass. Farmers associated less leafy biomass with improved competitive ability and agree across the environments that there is an optimal amount of leaves that ensures a harvest of both crops. One advantage of intercrops is the potential for increased light-use efficiency [45], and collective information from this study indicates there is an optimal plant structure that correlates with this competitive ability. As documented here, farmers reported that ideal genotypes had more leaves and pods at the base and a balance between sufficient leaves for plant growth while still enabling sunlight to penetrate. Baudoin et al. [42] and Davis and Woolley [46] have suggested this, although we are not aware of an ideal climbing bean structure for intercrops identified by researchers.

In all of the environments, farmers said the thickness of the bean stem and the vine was an important determinate of adaptability to the intercrop, but there were mixed views on whether it effected the plant physically or competitively. Some farmers associated a thick stem with lodging, while others said a smaller stem reduced competition with the maize plant. There is limited information from the literature indicating there is a preferable or 
advantageous stem thickness, although in a review Baudoin et al. [42] stated the probability of finding genotypes with a high harvest index and good yield depends on the plant architecture, and in Honduras, farmers involved in PPB processes, not surprisingly, identified thick stems as an ideal bean trait for bush beans [1]. Studies have looked at bean plant types and maize lodging, but to our knowledge there is no information on the effect of stem size on competition.

\section{Intrinsic competitive ability}

Evidence from both PPB discussions and the interviews highlighted that farmers identify an intrinsic competitive quality in bean genotypes (namely in Gasilida). This trait improves genotype performance in the intercrop, and some farmers stated they test the genotype by growing it in an intercrop to determine whether it has this quality. Breeders have found that competitive ability is a highly inherited trait in climbing beans [42], and farmers' conclusion that there are intrinsically competitive genotypes supports this argument. Other researcher-led trials have found evidence that there are genetic qualities that improve the competitive ability of a bean genotype in the intercrop. O'Leary and Smith [47] and Muraya et al. [24] showed that breeding maize in the intercrop from the onset improved genetic performance in that system, and Zimmerman et al. [40] and Davis and Woolley [46] concluded the same for beans. Despite these findings, plant breeders almost universally evaluate genotype performance in sole crops. Farmer identification of an intrinsic competitive quality is further evidence there are climbing beans better suited for an intercrop. While these can be identified late in the plant breeding process when cultivars are ready for release, we predict the introduction of line selection earlier in intercrop environments would result in identification of genotypes with superior competitive ability.

\section{Management}

Evidence from the interviews showed that farmers adjust the plant densities and timing of planting to optimize yield in their specific environment. Indeed, of the beanmaize breeding for intercropping research that exists, there are few similarities between the studies in terms of the intercrop plant density, plant type, or planting time $[30,36]$. Field experimentation has shown that even when the plant densities are held constant, the spatial arrangement can affect yield [48]. The variability of design in intercrop studies demonstrates the diversity found worldwide and the multitude of ways these systems can be constructed [49]. Vandermeer [17] suggests that modeling is key to formulating optimal intercrops in terms of spacing, density, and timing, but this would only be effective if the multiple services farmers desire from the cropping system are understood [50].

There was no consensus among farmers or researchers on optimal planting times for climbing beans in Rwanda, and this variability is evident in the literature. Several farmers indicated that beans should be planted two weeks after maize, but most stated that a four-week interval (used in the PPB trials) allowed the maize to grow tall enough in order to support the beans without being overgrown. Likewise researchers have found that aggressive climbing beans need to be planted some time after the maize to reduce smothering of the maize [46], but in contrast, unlike bush bean-maize intercrops, climbing beans have a greater yield potential with simultaneous plantings [51]. Farmers also stated that longer duration genotypes increased competition with the (180 day) maize. In general, farmers preferred earlier maturing genotypes, but they also stated that fewer days to maturity were better specifically in the maize intercrop environment. This is complementary to researchers' findings that there was less competition in a relay crop in which beans and maize overlap in the field for a brief period of time [46].

\section{The emergence of an ideotype}

Breeders have long used ideotype breeding to design varieties for unique production systems [52, 53]. Evidence from both PPB discussion groups and interviews was consistent in that farmers have preferred attributes that form an intercrop ideotype, and these include both traits and management strategies. The plant characteristics farmers preferred were traits related to reducing competition between bean and maize plants and included: early maturity, moderately aggressive and moderately shorter plant types with an even columnar distribution of largeseeded pods to prevent lodging, plants with fewer leaves (but not too few) to reduce competition for light, and that demonstrated adaptation. This would contrast with the more aggressive pyramid plant types that mature later and tend to set pods at the top of the plant creating uneven weight distribution that can result in shading and lodging of the maize plant. Adaptation and a natural competitive ability were of primary importance to farmers and essential to performance in the intercrop. Similar concerns with respect to plant morphology for intercropped climbing beans were identified in Guatemala (personal comm. Juan Jose Soto), and breeding strategies were proposed. These included developing less vigorous columnar types where the pods are set closer to the bean stem. Interestingly, in contrast to the bean-dominant intercropping system in Rwanda, intercrops in Guatemala are maize dominant (systems with a higher proportion of maize to beans). This is suggestive that some of the intercropping bean morphology identified here might 
be applicable even in maize-dominant systems. Hence, bean breeders could use these criteria to test and develop more genotypes suitable for intercrops in various regions.

\section{Adaptation and genetic variation}

Once genotypes are developed, the next step is testing adaptation across the intended environments. Both men and women in our study identified adaptation as an important trait, and they have established means of testing genotypes for adaptation in both sole and intercrop environments, on different fields. This underscores the challenges faced in crop improvement, given the magnitude of genotype by environment interactions and the heterogeneous environments of farming systems in East Africa. Farmers were highly aware of intercrops as an added source of complexity that required close attention in the genotype evaluation process. Although there is not consensus among researchers, our farmer discussion results align with those that agree germplasm should be selected in the sole crop for highly heritable traits such as seed color, maturity, adaptation to climatic factors [42], and then tested in the intercrop for quantitative traits such as competitive ability, yield potential, and stress tolerance $[42,46,54]$. Breeding for intercropping systems is challenging both for logistics and for resources; thus, this method also reduces some of that demand. However, an important caveat is that farmers in this study were not exposed to early segregating lines and the potential competitive advantage identified by some authors $[24,26]$.

The intercrop environment imposes competition for resources and environmental stress that may repress phenotypic expression of traits $[46,55]$. Evidence from this research and Voss' earlier work [9] shows that farmers are familiar with the effect of environmental stress, and Woolley and Davis [56] further note that farmers' cropping systems are fine-tuned to existing physical, biologi$\mathrm{cal}$, and socioeconomic determinants. These adjustments allow adaptation to changes in conditions [57], which may be static (soil types) or dynamic (weather). However, it is difficult to determine genetic variation within this context. From our study, there is evidence that farmers can, in these complex environments, identify genotypes with better competitive ability and are able to differentiate these traits from those that confer adaptation to edaphic and microclimatic stress. Corroborative evidence comes from a comparative study on farmers' concepts of heritability, where Cleveland and Soleri [58] found that most farmers distinguish between environmental variability and genotype by environment.

Given farmer knowledge demonstrated here, enabling farmer access to test advanced lines on-farm may improve the quality and quantity of bean cultivars produced. This runs counter to arguments that breeding within a sole crop environment is sufficient [59]. There are few studies testing this approach for breeding cultivars suited to intercrop systems. Atuahene-Amankwa et al. [23] used a selection intensity of $25 \%$ in a sole crop and found that the majority of high yielding lines were also high yielding in an intercrop. This study, however, was conducted on a Canadian research station in a resource-endowed environment with non-climbing Type I and II $F_{5}$ bean lines. The environmental stress and diversity of on-farm environments in Sub-Sahara Africa pose additional challenges, and our study suggests considerable benefits from incorporation of farmer knowledge and skills into selection strategies.

In our research, distinct environments existed within a modest radius and genotypes that performed well in one area did not necessarily succeed in another, a not uncommon situation [58]. Breeding for either low-input environments or intercropping systems is considered highly resource intensive and is often not feasible. However, our study has confirmed that farmers have considerable knowledge regarding selecting genotypes for diverse environments and multiple types of cropping systems. Involvement of farmers in early decision making and innovation with diverse genetic material has been shown to support co-evolution of genetic materials suitable to farmer fields [60]. This, combined with farmer participatory breeding programs that provide access to large and diverse bean populations, and attention to ideotype specificities, may be a feasible alternative to resource intensive intercrop genotype by environment field trials [61].

\section{Conclusions}

Bean farmers in Rwanda demonstrated sophisticated understanding of methods to identify genotype adaptation, competitive ability, and specific traits that together create an ideotype for maize-bean cropping systems. The ideotype traits identified included early maturity, less aggressive plant types, fewer leaves, columnar pod distribution, environmental adaptation, and competitive ability. Foremost in farmers' selection criteria attributes were yield and adaptation to the region. Further, some farmers combined knowledge of plant characteristics with an understanding of adaptation traits and management strategies to test germplasm in a manner to identify optimal genotypes for distinct cropping systems and field conditions. Interestingly, farmer observations highlighted that the best genotypes in the sole crop were not necessarily the best for intercrop systems, thus affirming plant breeders efforts (albeit limited) to develop strategies for breeding for mixed cropping system varieties.

This study showed further that improved bean germplasm, even recently released tested cultivars, is not necessarily adapted to the highly heterogeneous 
environments of smallholder cropping systems. The genotypes farmers preferred were the ones that have been in the region for decades (Gasilida and Ngwinurare). Adaptation to a region is essential for optimal performance, and farmers' strategies of testing genotypes in different field types and cropping systems are well suited to evaluate adaptation. Involvement of farmers in the selection process of early generation and diverse bean breeding populations through participatory breeding approaches that involve hundreds of farmers could improve identification of adapted, superior genotypes. Breeding programs designed specifically for intercropping systems are normally considered cumbersome and expensive, but empowering farmers through on-farm testing of diverse genotypes, and even populations, could be a practical solution and improve the productivity of these diverse cropping systems.

Finally, this study affirms that PPB approaches are essential for crop improvement and that farmer knowledge complements and can contribute substantially to breeding efforts. PPB was developed to collaboratively identify and develop improved varieties specifically for marginalized communities. This work expands the application of PPB to marginalized mixed cropping systems, and this, combined with analysis of in-depth interviews and scientific findings, generated new knowledge concerning bean-maize intercropping systems.

\section{Abbreviations}

IRB: Internal Review Board; PPB: participatory plant breeding.

\section{Authors' contributions}

$\mathrm{KI}$ and SS conceptualized the research and design of the participatory on-farm trials. KI conceptualized and developed the interviews and carried out all of the research in Rwanda, with substantial contributions to bean genotype data collection methods and theory from JK. KC contributed to the interview methodology and analysis approach. JK identified the emergence of an ideotype from the analysis. KI drafted the manuscript, and SS, JK, and KC provided substantial revisions. All authors read and approved the final manuscript.

\section{Author details}

${ }^{1}$ International Crops Research Institute for the Semi-Arid Tropics (ICRISAT), BP 320, Bamako, Mali. ${ }^{2}$ Department of Plant, Soil, and Microbial Sciences, Michigan State University, 286 Plant and Soil Science Building, East Lansing, MI 48824, USA. ${ }^{3}$ Department of Community Sustainability, Michigan State University, Natural Resource Building, 480 Wilson Road, East Lansing, MI 48824, USA.

\section{Acknowledgements}

The authors wish to thank all of the farmer association members who openly participated and contributed their knowledge and interest to this study. We would like to acknowledge Rural Northern Development (DERN) for providing assistance and staff resources in this study and thank the plant breeder Louis Butare from Rwanda Agriculture Board (RAB) for logistical support and help in choosing the varieties used in this study. We are especially grateful to Faustin Nshimiyimana (DERN) for providing facilitation, translation, and field assistance in the research locations. Finally, we wish to thank the anonymous reviewers for their very thoughtful and useful comments.

\section{Competing interests}

The authors declare that they have no competing interests.

\section{Ethics approval and consent to participate}

The study was approved by the Internal Review Board of Michigan State University (IRB\#: x10-1130) and considered exempt. Informed consent was obtained from all the participants. Country-level research permission in Rwanda was granted from the Rwanda Agricultural Board, and at each district level, agricultural authority permission was requested and granted.

\section{Funding}

This work was supported by the US Agency for International Development (USAID) through the Dry Grain Pulses Collaborative Research Support Program under Cooperative Agreement EDH-A-00-07-00005-00 and the FulbrightHayes Doctoral Dissertation Fellowship. The content is solely the responsibility of the author(s) and does not necessarily represent the official views of the US Agency for International Development (USAID).

Received: 26 April 2016 Accepted: 14 July 2016

Published online: 08 August 2016

\section{References}

1. Humphries S, Rosas JC, Gómez M, Jiménez J, Sierra F, Gallardo O, Avila C, Barahona M. Synergies at the interface of farmer-scientist partnerships: agricultural innovation through participatory research and plant breeding in Honduras. Agric Food Secur. 2015;4:27.

2. Morris M, Bellon M. Participatory plant breeding research: opportunities and challenges for the international crop improvement system. Euphytica. 2004;136:21-35.

3. Weltzien E, Smith ME, Meitzner LS, Sperling L. Technical and institutional issues in participatory plant breeding-from the perspective of formal plant breeding. Volume PPB Monograph 1. Cali, Colombia: CIAT; 2003.

4. Witcombe JR, Johansen C, Virk VDS, Sthapit BR, Joshi KD, Gyawali S, Musa AM. Participatory plant breeding is better described as highly clientoriented plant breeding I Four indicators of client-orientation in plant breeding. Exp Agric. 2005;41:299-319.

5. Ceccarelli S, Grando S. Decentralized-participatory plant breeding: an example of demand driven research. Euphytica. 2007;155:349-60.

6. Witcombe JR. Decentralization versus farmer participation in plant breeding : some methodology issues. CIAT Publ No 294 CIAT; 1997.

7. Dawson JC, Jones SS, Murphy KM. Decentralized selection and participatory approaches in plant breeding for low-input systems [electronic resource]. Euphytica. 2008;160:143-54.

8. Sperling L, Berkowitz P. Partners in selection: bean breeders and women bean experts in Rwanda. Washington, DC: CGIAR Gender Program; 1994.

9. Voss J. Conserving and increasing on-farm genetic diversity: farmer management of varietal bean mixtures. In: Utilizing and conserving agrobiodiversity in agricultural landscapes. Cornell University Press; 1993.

10. Birol E, Villalba ER, Smale M. Farmer preferences for milpa diversity and genetically modified maize in Mexico: a latent class approach. Environ Dev Econ. 2009;14(4):521-40.

11. Vandermeer JH. The ecology of intercropping. Cambridge: Cambridge University Press; 1992.

12. Lithourgidis AS, Dordas CA, Damalas CA, Vlachostergios DN. Annual intercrops: an alternative pathway for sustainable agriculture. Aust J Crop Sci. 2011;5:396-410.

13. Altieri MA. Linking ecologists and traditional farmers in the search for sustainable agriculture. Front Ecol Environ. 2004;2:35-42.

14. Mead R, Willey RW. The concept of a "land equivalent ratio" and advantages in yields from intercropping. Exp Agric. 1980;16:217-28.

15. Seran TH, Brintha I. Review on maize based intercropping. J Agron. 2010;9:135-45.

16. Gliessman SR. Agroecology in the tropics: achieving a balance between land use and preservation. Environ Manage. 1992;16:681-9.

17. Vandermeer JH. The ecology of agroecosystems. Sudbury, MA: Jones and Bartlett Publishers; 2011. 
18. Jackson LE, Pascual U, Hodgkin T. Utilizing and conserving agrobiodiversity in agricultural landscapes. Agric Ecosyst Environ. 2007;121:196-210.

19. Broughton WJ, Hernández G, Blair M, Beebe S, Gepts P, Vanderleyden J. Beans (Phaseolus spp.) —-model food legumes. Plant Soil. 2003;252:55-128.

20. Broughton WJ, Hernández G, Blair M, Beebe S, Gepts P, Vanderleyden J. Beans (Phaseolus spp.) —-model food legumes. Plant Soil. 2003;252:55-128.

21. Isaacs KB, Snapp SS, Chung K, Waldman KB. Assessing the value of diverse cropping systems under a new agricultural policy environment in Rwanda. Food Secur. 2016:8:491-506.

22. Stern WR. Nitrogen fixation and transfer in intercrop systems [Intercropping-Bases of Productivity]. Field Crops Res. 1993, 34:335-56.

23. Atuahene-Amankwa G, Beatie AD, Michaels TE, Falk DE. Cropping system evaluation and selection of common bean genotypes for a maize/bean intercrop. Afr Crop Sci J. 2004;12:105-13.

24. Muraya MM, Omolo EO, Ndirangu CM. Development of high yielding synthetic maize (Zea mays L.) varieties suitable for intercropping with common bean (Phaseolus vulgaris L.). Asian J Plant Sci. 2006;5:163-9.

25. O'Leary N, Smith ME. Uncovering corn adaptation to intercrop with bean by selecting for system yield in the intercrop environment. J Sustain Agric. 2004;24:109.

26. Zimmermann MJO. Breeding for yield, in mixtures of common beans (Phaseolus vulgaris L.) and maize (Zea mays L.). Euphytica. 1996;92:129-34.

27. Tsubo M, Walker S, Ogindo HO. A simulation model of cereal-legume intercropping systems for semi-arid regions: II. Model application. Field Crops Res. 2005;93:23-33.

28. Isaacs KB. Rediscovering the value of crop diversity in Rwanda: participatory variety selection and genotype by cropping system interactions in bean and maize systems. East Lansing: Michigan State University; 2014.

29. Davis JHC, Garcia S. Competitive ability and growth habit of indeterminate beans and maize for intercropping. Field Crops Res. 1983;6:59-75.

30. Francis CA, Prager M, Laing DR, Flor CA. Genotype $\times$ environment interactions in bush bean cultivars in monoculture and associated with maize. Crop Sci. 1978;18:237-42.

31. Santalla M, Lema M, Rodiño AP, González AM, Monteagudo AB, Ron AMD. Improvement of large-seeded common bean cultivars under sustainable cropping systems in Spain. Euphytica. 2005;142:85-95.

32. Gebeyehu S, Simane B, Kirkby R. Genotype $\times$ cropping system interaction in climbing beans (Phaseolus vulgaris L.) grown as sole crop and in association with maize (Zea mays L.). Eur J Agron. 2006;24:396-403.

33. Worku W. Evaluation of common bean (Phaseolus vulgaris L.) genotypes of diverse growth habit under sole and intercropping with maize (Zea mays L.) in Southern Ethiopia. J Agron. 2008;7:306-13.

34. Sperling $L$, Loevinsohn ME, Ntabomvura B. Rethinking the farmer's role in plant breeding: local bean experts and on-station selection in Rwanda. Exp Agric. 1993;29:509-19.

35. Voss J. Conserving and increasing on-farm genetic diversity: farmer management of varietal bean mixtures. In: Moock JL, Rhodes RE, editors. Utilizing and conserving agrobiodiversity in agricultural landscapes. Ithaca: Cornell University Press; 1992. p. 34-51.

36. Santalla M, de Ron AM, Escribano MR. Effect of intercropping bush bean populations with maize on agronomic traits and their implications for selection. Field Crops Res. 1994;36:185-9.

37. Friesen DK, Palmer AFE (Eds). Integrated approaches to higher maize productivity in the new millennium: proceedings of the seventh eastern and southern Africa regional maize conference, Nairobi, Kenya, 5-11 February 2002. [Nairobi]: CIMMYT, African Livelihoods Program : Kenya Agricultural Research Institute; 2004

38. Miles MB, Huberman AM, Saldaña J. Qualitative data analysis: a methods sourcebook. Beverly Hills: SAGE; 2013.

39. Howe G, McKay A. Combining quantitative and qualitative methods in assessing chronic poverty: the case of Rwanda [Experiences of Combining Qualitative and Quantitative Approaches in Poverty Analysis]. World Dev 2007, 35:197-211.

40. Zimmermann MJO, Rosielle AA, Waines JG, Foster KW. A heritability and correlation study of grain yield, yield components, and harvest index of common bean in sole crop and intercrop. Field Crops Res. 1984;9:109-18.

41. Pfeiffer JM, Butz RJ. Assessing cultural and ecological variation in ethnobiological research: the importance of gender. J Ethnobiol. 2005;25:240-78.
42. Baudoin JP, Camarena F, Lobo M. Improving Phaseolus genotypes for multiple cropping systems. Euphytica. 1997;96:115-23.

43. Wortmann CS, Sengooba T. The banana-bean intercropping system-bean genotype $\times$ cropping system interactions. Field Crops Res. 1993;31:19-25.

44. Musoni A, Kayumba J, Butare L, Mukamuhirwa F, Murwanashyaka E, Mukankubana D, Kelly JD, Ininda J, Gahakwa D. Innovations to overcome staking challenges to growing climbing beans by smallholders in Rwanda. In: Vanlauwe B, van Asten P, Blomme G, editors. Challenges and opportunities for agricultural intensification of the humid highland systems of Sub-Saharan Africa. New York: Springer International Publishing; 2014. p. 129-36.

45. Tsubo M, Mukhala E, Ogindo HO, Walker S. Productivity of maizebean intercropping in a semi-arid region of South Africa. Water SA. 2004:29:381-8.

46. Davis JHC, Woolley JN. Genotypic requirement for intercropping. Field Crops Res. 1993;34:407-30.

47. O'Leary N, Smith ME. Breeding corn for adaptation to two diverse intercropping companions. Am J Altern Agric 1999, 14:158-64.

48. de Raposo JA, Schuch LOB, de Assis FN, Machado AA. Intercropping of maize and beans in different plant arrangements and densities in Pelotas, Rio Grande do Sul. Pesqui Agropecu Bras 1995, 30:639-47.

49. Graham PH, Ranalli P. Common bean (Phaseolus vulgaris L.). Field Crops Res. 1997;53:131-46.

50. Snapp S, Kerr RB, Smith A, Ollenburger M, Mhango W, Shumba L, Gondwe T, Kanyama-Phiri G. Modeling and participatory farmer-led approaches to food security in a changing world: a case study from Malawi. Sci Chang Planétaires Sécher. 2013;24:350-8.

51. Francis CA. Development of plant genotypes for multiple cropping systems. Ames, lowa: lowa State Univ. Press; 1981.

52. Donald CM. The breeding of crop ideotypes. Euphytica. 1968;17:385-403.

53. Kelly JD, Adams MW. Phenotypic recurrent selection in ideotype breeding of pinto beans. Euphytica. 1987;36:69-80.

54. Francis CA, Smith ME. Variety development for multiple cropping systems. Crit Rev Plant Sci. 1985;3:133-68.

55. Bänziger $M$, Cooper $M$. Breeding for low input conditions and consequences for participatory plant breeding examples from tropical maize and wheat. Euphytica. 2001;122:503-19.

56. Woolley J, Davis JHC. The agronomy of intercropping with beans. In Common beans: research for crop improvement; 1991. p. 707-35.

57. Davis JHC, Woolley JN. Genotypic requirement for intercropping. Field Crops Res. 1993;34:407-30.

58. Cleveland DA, Soleri D. Farmers, scientists and plant breeding: integrating knowledge and practice. CABI; 2002.

59. Duc G, Agrama H, Bao S, Berger J, Bourion V, De Ron AM, Gowda CLL, Mikic A, Millot D, Singh KB, Tullu A, Vandenberg A, Vaz Patto MC, Warkentin TD, Zong $X$. Breeding annual grain legumes for sustainable agriculture: new methods to approach complex traits and target new cultivar ideotypes. Crit Rev Plant Sci. 2015;34:381-411.

60. Li J, Lammerts van Bueren ET, Huang K, Qin L, Song Y. The potential of participatory hybrid breeding. Int J Agric Sustain. 2013;11:234-51.

61. Soleri D, Cleveland DA. Breeding for quantitative variables. Part 1: Farmers' and scientists' knowledge and practice in variety choice and plant selection. In Plant breeding and farmer participation. FAO; 2009.

\section{Submit your next manuscript to BioMed Central} and we will help you at every step:

- We accept pre-submission inquiries

- Our selector tool helps you to find the most relevant journal

- We provide round the clock customer support

- Convenient online submission

- Thorough peer review

- Inclusion in PubMed and all major indexing services

- Maximum visibility for your research

Submit your manuscript at www.biomedcentral.com/submit 